DOI: $10.38035 /$ JEMSI

Received: 24 Juni 2020, Revised: 25 Agustus 2020, Publish: 15 September 2020



\title{
SISTEM PENDUKUNG KEPUTUSAN PENILAIAN KINERJA KARYAWAN MENGGUNAKAN METODE ELIMINATION ET CHOIX TRADUISANT LA REALITE
}

\author{
Hadi Syahputra ${ }^{1}$, Dodi Guswandi ${ }^{2}$, Desi Permata Sari $^{3}$ \\ ${ }^{1)}$ Universitas Putra Indonesia "YPTK" Padang, Indonesia, \\ hadisyahputra82@upiyptk.ac.id \\ ${ }^{2)}$ Universitas Putra Indonesia "YPTK" Padang, Indonesia, guswandidodi @ upiyptk.ac.id \\ ${ }^{3)}$ Universitas Putra Indonesia "YPTK" Padang, Indonesia, \\ desipermatasari@upiyptk.ac.id
}

\section{Corresponding Author: First Author ${ }^{1}$}

Abstrak: Kualitas sumber daya manusia merupakan salah satu faktor penunjang untuk meningkatkan produktivitas kinerja suatu instansi. Maka dari itu sumber daya manusia yang berkompetensi tinggi dapat mendukung tingkat kinerja, dengan penilaian kinerja maka akan diketahui prestasi yang dicapai setiap karyawan. Penelitian ini bertujuan untuk membantu manajer Konveksi Sahabat dalam menilai kinerja karyawan dalam menjahit berbagai jenis pakaian, bagi karyawan yang kinerjanya baik akan diperpanjang kontrak kerjanya. Konveksi Sahabat menerima pesanan dan borongan jahitan pakaian dari pelanggan baik perorangan maupun suatu instansi pemerintah dan swasta. Metode sistem pendukung keputusan yang digunakan dalam mengolah data adalah Elimination Et Choix Traduisant La Realite (ELECTRE). Hasil penelitian ini membantu manager Konveksi Sahabat dalam melakukan penilaian kinerja karyawan terbaik dengan analisa sistem secara manual menggunakan metode Elimination Et Choix Traduisant La Realite (ELECTRE) yang dapat mengeliminasi dan merangking alternatif terbaik sehingga manajer Konveksi Sahabat dapat mengambil keputusan tepat dan akurat.

Kata Kunci: Konveksi Sahabat, Sistem Pendukung Keputusan, Metode Elimination Et Choix Traduisant La Realite

\section{PENDAHULUAN}

Manajemen Sumber Daya Manusia (MSDM) adalah suatu proses menangani berbagai masalah pada ruang lingkup karyawan, pegawai, manajer dan tenaga lainnya untuk dapat menunjang aktivitas organisasi perusahaan demi mencapai tujuan yang telah ditentukan. Salah satu elemen dalam perusahaan yang sangat penting adalah Sumber Daya Manusia (SDM). SDM dari suatu perusahaan sangat mempengaruhi banyak aspek penentu keberhasilan kerja dari perusahaan tersebut. Prestasi kerja adalah suatu bentuk dari hasil kerja seorang karyawan, hasil kerja tersebut nantinya akan dinilai oleh atasan maupun perusahaan. Prestasi kerja seorang karyawan tidak 
selamanya baik, ada yang bagus dan ada juga yang buruk. Maka dari itu setiap karyawan suatu organisasi atau perusahaan pasti akan berusaha untuk mendapatkan hasil kerja yang baik. Kualitas kerja seorang karyawan sangatlah berpengaruh dalam prestasi karyawan perusahaan. Yang dimana hal inilah yang menjadi pertimbangan seorang atasan atau manajer dalam memberikan penilaian. Kualitas yang dimaksud adalah pada saat melakukan kegiatan kerja, seorang karyawan mampu menunjukan kualitas SDM yang dimilikinya dengan memberikan kontribusi yang maksimal terhadap perusahaan tempat ia bekerja [1] Mesran, Selpi Anita, Ronda Deli Sianturi

Sistem pendukung keputusan merupakan suatu sistem informasi spesifik yang ditujukan untuk membantu manajemen dalam mengambil keputusan yang berkaitan dengan persoalan yang bersifat semi terstruktur. System ini memiliki fasilitas untuk menghasilkan berbagai alternatif yang secara interaktif digunakan oleh pemakai. Pengambilan keputusan merupakan bagian kunci kegiatan setiap manusia dalam kehidupannya. Masalah yang biasa ditemui saat dilakukannya pengambilan keputusan yaitu tidak terdapatnya informasi yang cukup, atau informasi terlampau banyak, kurangnya keakuratan informasi, tidak memiliki kemampuan dalam melakukan penganalisaan terhadap masalah yang ditemui (Nofriansyah \& Defit, 2018). Begitu juga saat pengambilan keputusan penilaian kinerja karyawan pada Konveksi Sahabat . [2] (Sarjon)

Pada penelitian ini dibangun Sistem pendukung keputusan menggunakan metode analisis pengambilan keputusan multikriteria yaitu ELECTRE. Metode ELECTRE merupakan satu dari beberapa metode dalam pengambilan keputusan yang berbasis multikriteria. Penerapan ELECTRE berdasarkan kriteria yang terdapat dalam konsep outranking. Dalam penerapannya, ELECTRE menggunakan perbandingan yang berpasangan, dari setiap alternative pada kriteria-kriteria yang sesuai. Metode ini diterapkan dalam kondisi alternatif yang kurang sesuai terhadap kriteria yang akan dieliminasi, dan alternatif yang sesuai dengan kriteria. Sehingga ELECTRE tepat digunakan pada kasus-kasus yang memiliki banyak alternatif dengan sedikit kriteria.[3] Mesran, Pristiwanto, Dormian Sihombing

Berdasarkan latar belakang dan rumusan masalah tersebut, dilakukanlah penelitian sistem pendukung keputusan menggunakan metode Elimination Et Choix Traduisant La Realite yang dapat nantinya diimplementasikan kedalam bahasa pemrograman Java dan database MySQL dalam mengolah dan menyimpan data karyawan. Penelitian ini diharapkan dapat membantu manajer Konveksi Sahabat dalam mengambil keputusan penilaian kinerja karyawan dengan mudah dan cepat.

\section{METODE PENELITIAN}

Dalam metode penelitian ini ada beberapa urutan kerangka kerja yang digunakan pada gambar 1, berikut ini: 


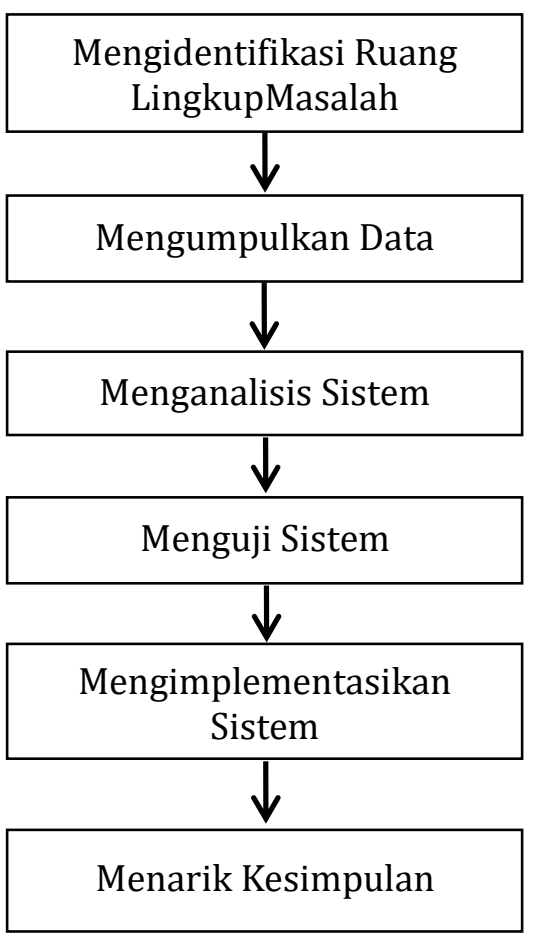

Gambar 1. Kerangka Penelitian

Dari kerangka penelitian Gambar 1, dapat dijelaskan masing-masing langkah kerja sebagai berikut :

1. Mengidentifikasi ruang lingkup masalah

Ruang lingkup masalah harus ditentukan terlebih dahulu karena tahapan ini mengindentifikasi masalah yang dimulai dari mempelajari, mengumpulkan data, kemudian menganalisa.

2. Mengumpulkan data

Dalam tahap pengumpulan data dilakukan dengan cara melakukan langsung observasi pada manajer Konveksi Sahabat .

3. Menganalisa sistem

Analisis sistem (system analysis) dapat didefinisikan sebagai penguraian dari suatu sistem mengidentifikasikan dan mengevaluasi permasalahan-permasalahan, kesempatan-kesempatan, hamabatan-hambatan yang terjadi dan kebutuhankebutuhan yang diharapkan sehingga dapat diusulkan perbaikan-perbaikannya.

4. Menguji Sistem

Pengujian sistem dilakukan dalam bentuk konsep dari perancangan sistem pendukung keputusan dalam menentukan kinerja karyawan.

5. Mengimplementasikan Sistem

Pada tahap ini dilakukan pengkajian kembali kelayakan dari pada sistem pendukung keputusan yang telah dirancang. Apakah sistem tersebut sudah sesuai atau masih perlu dilakukan peninjauan kembali atau dilakukan perbaikan.

6. Menarik Kesimpulan

Setelah implementasi sistem dilakukan dan hasil yang diinginkan telah sesuai dengan alnalisis metode yang digunakan, maka dapat ditarik sebuah kesimpulan bahwa metode Elimination Et Choix Traduisant La Realite tepat digunakan dalam permasalahan dalam proses pengambilan keputusan penilaian kinerja karyawan Konveksi Sahabat . 


\section{HASIL DAN PEMBAHASAN}

Sistem Pendukung Keputusan

Sistem pendukung keputusan merupakan suatu sistem yang dapat secara interaktif dalam pengambilan keputusan melalui pengguna data dan model-model keputusan untuk memecahkan masalah-masalah yang sifatnya semi terstruktur dan tidak terstruktur.

\section{Elimination Et Choix Traduisant La Realite (ELECTRE)}

ELECTRE merupakan salah satu metode pengambilan keputusan dengan banyak kriteria. Metode ini menggunakan konsep Outranking dimana alternatif- alternatif yang ada dipasangkan kemudian dbandingkan bedasarkan kriteria yang sesuai. Metode ini pertama kali diusulkan oleh Bernad Roy dan rekan-rekannya di perusahaan konsultan SEMA (Specialty Equipment Market Association) pada tahun 1965. Metode ELECTRE merupakan metode pemilihan aksi terbaik darisekumpulan aksi yang ada, dengan melakukan tiga aksi yakni : memilih, menyortir dan memberi peringkat. Metode electre digunakan padakondisi dimana alternatif yang kurang sesuaidengan kriteria dieliminasi, dan alternatif yang sesuai dapat dihasilkan. Dengan katalain, electre digunakan untuk kasus-kasusdengan banyak alternatif namunhanyasedikit kriteria yang dilibatkan. Dalam menyelesaikan suatu masala, metode ELECTRE menggunakan langkah-langkah sebagai berikut:

Langkah 1: Melakukan normalisasi pada matrik keputusan.

Langkah pertama adalah dengan mengubah setiap atribut diubah menjadi nilai yang dapat dibandingkan (comparable), dimana setiap normalisasi dari nilai rij.adalah:

$$
r i j=\frac{x i j}{\sqrt{\sum_{i=1}^{m} x^{2} i j}}
$$

Untuk $i=1,2,3, \ldots, m$ dan $j=1,2,3, \ldots, n$.

Dari hasil normalisasi tersebut, sehingga didapat matriks $r_{i j}$

$$
r i j=\left[\begin{array}{cccc}
r 11 & r 12 & \ldots & r 1 n \\
r 21 & r 22 & \ldots & r 2 n \\
r m 1 & r m 2 & \ldots & r m n
\end{array}\right]
$$

Langkah 2: Pembobotan pada matrik yang telah dinormalisasi.

Pada tahap ini, bobot-bobot $\left(\mathrm{w}_{\mathrm{j}}\right)$ yang telah ditentukan oleh pembuat keputusan dikalikan dengan setiap kolom dari matrik $R$ sehingga diperoleh weighted normalized matrix sebagai berikut:

$$
\begin{aligned}
\mathrm{V}_{\mathrm{ij}} & =\mathrm{r}_{\mathrm{ij}} \cdot \mathrm{w}_{\mathrm{j}} \\
V i j & =\left[\begin{array}{llll}
w_{1} r_{11} & w_{2} r_{12} & \ldots & w_{n} r_{1 n} \\
w_{1} r_{21} & w_{2} r_{22} & \ldots & w_{n} r_{2 n} \\
w_{1} r_{m 1} & w_{2} r_{m 2} & \ldots & w_{n} r_{m n}
\end{array}\right]
\end{aligned}
$$

Langkah 3: Menentukan concordance dan discordance set.

Pada tahap ini, setiap pasang dari alternative $\mathrm{k}$ dan $1(\mathrm{k}, \mathrm{l}=1,2,3, \ldots, \mathrm{m}$ dan $\mathrm{k} \neq 1)$ kumpulan kriteria J dibagi ke dalam dua subsets, yaitu concordace dan discordance.

Subsets concordance memiliki kriteria sebagai berikut:

$\mathrm{C}_{\mathrm{kl}}=\left\{\mathrm{j}, \mathrm{y}_{\mathrm{kj}} \geq \mathrm{y}_{\mathrm{lj}}\right\}$, untuk $\mathrm{j}=1,2,3, \ldots, \mathrm{n}$

Sedangkan kriteria dari subset discordance adalah sebagai berikut:

$\mathrm{D}_{\mathrm{kl}}==\left\{\mathrm{j}, \mathrm{y}_{\mathrm{kj}}<\mathrm{y}_{\mathrm{lj}}\right\}$, untuk $\mathrm{j}=1,2,3, \ldots, \mathrm{n}$

Langkah 4: Menghitung matriks concordance dan discordance.

\section{a. Concordance}

Pada tahap ini, bobot-bobot yang termasuk dalam subset concordance dihitung untuk menentukan nilai dari elemen-elemen pada matriks concordance dengan rumus sebagai berikut: 


$$
C_{k l}=\sum_{j C_{w}} w j
$$

Matriks Concordance adalah:

$$
r i j=\left[\begin{array}{cccc}
- & C_{12} & \ldots & C_{1 m} \\
C_{21} & - & \ldots & C_{2 m} \\
C_{m 1} & C_{m 2} & \ldots & -
\end{array}\right]
$$

\section{b. Discordance}

Nilai dari elemen-elemen pada matriks discordance dihitung dengan membagi maksimum selisih nilai criteria yang termasuk dalam subset discordance dengan maksimum selisih nilai seluruh kriteria yang telah ditentukan.

$$
D k l=\frac{\max \{|\mathrm{Vkj}-\mathrm{Vlj}|\} \mathrm{j} \in \mathrm{Dkl}}{\max \{|V k j-V l j|\} \forall j}
$$

Maka diperoleh matriks Discordance:

$$
D=\left[\begin{array}{cccc}
- & d_{12} & \ldots & d_{1 m} \\
d_{21} & - & \ldots & d_{2 m} \\
d_{m 1} & d_{m 2} & \ldots & -
\end{array}\right]
$$

Langkah 5: Menentukan matrik dominan concordance dan discordance.

\section{a. Concordance}

Untuk membangun matrik dominan concordance maka digunakan nilai threshold. Nilai ini diperoleh dengan membandingkan setiap nilai elemen matriks concordance dengan nilai threshold. $\mathrm{Ckl} \geq \underline{C}$ dengan nilai threshold $(\underline{c})$, sebagai berikut:

$$
\underline{C}=\frac{\sum_{k=1}^{n} \sum_{l=1}^{n} c_{k l}}{m \times(m-1)}
$$

Dan nilai setiap elemen matriks $F$ sebagai matriks dominan concordance.

$$
f_{k l}=1, \text { jika } \mathrm{c}_{\mathrm{kl}} \geq \underline{\mathrm{c}} \operatorname{dan} f_{k l}=0, \text { jika } \mathrm{c}_{\mathrm{kl}}<\underline{\mathrm{c}}
$$

\section{b. Discordance}

Demikian juga dengan matriks dominan discordance, bisa dibangun dengan menggunakan nilai threshold.

$$
d=\frac{\sum_{k=1}^{n} \sum_{l=1}^{n} d_{k l}}{m \times(m-1)}
$$

Dan nilai setiap elemen matriks $G$ sebagai matriks dominan discordance.

$$
g_{k l}=1, \text { jika c} \mathrm{kl}_{\mathrm{kl}} \geq \underline{\mathrm{c}} \text { dan } f_{k l}=0, \text { jika } \mathrm{c}_{\mathrm{kl}}<\underline{\mathrm{c}}
$$

Langkah 6 : Menentukan aggregate dominance matriks

Pada tahap ini, setiap hasil perkalian antara elemen matriks $F$ dengan elemen matriks $G$ menentukan aggregate dominance matriks sebagai matriks E, seperti berikut ini:

$$
e_{\mathrm{kl}}=\mathrm{f}_{\mathrm{kl}} \times \mathrm{g}_{\mathrm{kl}}
$$

Langkah 7 : Mengeliminasi alternative yang kurang menguntungkan (less favourable).

Pada tahap ini, dipilih alternative terbaik yang mendominasi alternative lainnya. Urutan dari setiap alternative pilihan dapat dilihat pada matriks E dimana apabila e $k l=$ 1 maka alternative Ak merupakan pilihan yang lebih baik dibandingkan A1. Dengan demikian baris dalam matriks E yang memiliki jumlah e $k l=1$ atau yang paling sedikit dapat dieliminasi.

\section{Penyelesaian kasus}

Dalam penilaian kinerja karyawan pada Konveksi Sahabat, terdapat beberapa kriteria yang didapatkan dari hasil wawancara dengan owner Konveksi Sahabat , sebagai berikut:

Tabel 1. Kriteria Penilaian

\begin{tabular}{lll}
\hline NO & Kode Kriteria & Nama Kriteria \\
\hline
\end{tabular}




\begin{tabular}{cll}
\hline 1 & C1 & Disiplin \\
2 & C2 & Kehadiran \\
3 & C3 & Tanggung Jawab \\
4 & C4 & Kerjasama \\
5 & C5 & Kejujuran \\
6 & C6 & Masa Kerja \\
7 & C7 & Target Borongan \\
8 & C8 & Kerapian Jahitan \\
9 & C9 & Komunikasi \\
10 & C10 & Kepribadian \\
\hline
\end{tabular}

Kriteria penilaian terdiri dari 10 yaitu Disiplin, Kehadiran, Tanggung Jawab, Kerjasama, Kejujuran, Masa Kerja, Target Borongan, Kerapian Jahitan, Komunikasi, dan Kepribadian. Setiap kriteria diberi kode C1, C2, C3, C4, C5, C6, C7, C8, C9, dan C10.

\section{Menentukan Bobot Kriteria}

Rating kecocokan setiap alternative (penilaian) pada setiap kriteria dari nilai tertinggi sampai terendah pada tabel 2.

Tabel 2. Preferensi Bobot Tiap Kriteria

\begin{tabular}{clc}
\hline Kode & \multicolumn{1}{c}{ Kriteria } & Bobot \\
\hline C1 & Disiplin & 4 \\
C2 & Kehadiran & 3 \\
C3 & Tanggung Jawab & 5 \\
C4 & Kerjasama & 2 \\
C5 & Kejujuran & 4 \\
C6 & Masa Kerja & 2 \\
C7 & Target Borongan & 5 \\
C8 & Kerapian Jahitan & 4 \\
C9 & Komunikasi & 2 \\
C10 & Kepribadian & 5 \\
\hline
\end{tabular}

Dari tabel di atas dapat dilihat bahwa setiap kriteria diberi bobot pada masingmasing kriteria yaitu pada kriteria disiplin, kejujuran, kerapian jahitan diberi bobot 4, kriteria kehadiran diberi bobot 3, kriteria tanggung jawab, target borongan, kepribadian diberi bobot 5, dan kriteria kerjasama, masa kerja, komunikasi diberi bobot 2 .

\section{Menentukan nilai rating kriteria kecocokan}

A. Kriteria Disiplin (C1)

Penilaian kedisiplinan merupakan nilai ketepatan waktu kedatangan karyawan pada jam kerja yang sudah ditentukan, ada karyawan yang datang tepat waktu dan datang lebih awal akan mendapatkan penilaian yang tinggi, sedangkan karyawan yang sering datang terlambat mendapatkan nilai yang rendah.

Tabel 3. Komposisi Kriteria Disiplin

\begin{tabular}{ccc}
\hline Kriteria & \multicolumn{1}{c}{ Sub Kriteria } & Nilai \\
\hline Disiplin & $\begin{array}{l}\text { Sering datang terlambat dan absen tanpa alasan yang jelas } \\
\text { datang kadang terlambat }\end{array}$ & 1 \\
& 2
\end{tabular}


Selalu hadir tetapi kadang terlambat dan sesekali absen 3 dibeberapa kondisi yang bisa diberi toleransi

Selalu hadir tepat waktu, dengan tingkat absensi $<5 \%$ 3

Selalu hadir tepat waktu, dengan tingkat absensi $0 \%$

4

5

Penilaian kedisiplin mempunyai 5 item sub penilaian yang akan diberikan Nilai bobot dengan range 1-5 artinya semakin besar bobot angka penilaian semakin baik dan bagus.

B. Kriteria Kehadiran (C2)

Penilaian kehadiran adalah nilai absensi kedatangan karyawan pada hari kerja yang sudah ditentukan yaitu pada senin sampai sabtu. Karyawan yang sering tidak hadir akan mendapatkan penilaian yang rendah, begitu sebaliknya bagi karyawan yang kehadirannya maximal memperoleh nilai yang terbaik.

Tabel 4. Komposisi Kriteria Kehadiran

\begin{tabular}{ccc}
\hline Kriteria & Sub Kriteria & Nilai \\
\hline \multirow{3}{*}{ Kehadiran } & $<20,00 \%$ & 1 \\
& $20,00<\mathrm{x}<40,00 \%$ & 2 \\
& $40,00<\mathrm{x}<60,00 \%$ & 3 \\
$60,00<\mathrm{x}<80,00$ & 4 \\
& $80,00<\mathrm{x}<100 \%$ & 5 \\
\hline
\end{tabular}

Kriteria kehadiran mempunyai sub kriteria penilaian yang dimulai dari 20\%-100\% dan setiap sub kriteria mempunyai nilai bobot 1 sampai 5, semakin tinggi nilai range sub kriteria, maka semakin tinggi nilai bobotnya.

C. Kriteria Tanggung Jawab (C3)

Kriteria tanggung jawab merupakan borongan tugas jahitan yang diberikan oleh manajer Konveksi Sahabat kepada karyawan untuk diselesaikan sesuai dengan permintaan pelanggan dan dapat diselesaikan tepat pada waktu yang telah ditentukan.

Tabel 5. Komposis Kriteria Tanggung Jawab

\begin{tabular}{clc}
\hline Kriteria & \multicolumn{1}{c}{ Sub Kriteria } & Nilai \\
\hline & $\begin{array}{l}\text { Sering kali tidak mengerjakan tugas yang diberikan } \\
\text { Tugas yang diberikan dikerjakan namun kerap kali terlambat dan } \\
\text { Tanggung } \\
\text { Jawab }\end{array}$ & 2 \\
& $\begin{array}{l}\text { Manyak ditemui kesalahan } \\
\text { kurang serjakan tugas yang diberikan terkadang terlambat dan }\end{array}$ & 3 \\
& $\begin{array}{l}\text { Selalu mengerjakan tugas yang diberikan dengan tepat waktu } \\
\text { meskipun sesekali melakukan kesalahan }\end{array}$ & 4 \\
& $\begin{array}{l}\text { Selalu mengerjakan tugas yang diberikan, mengumpulkan tepat } \\
\text { waktu, serta mengerjakan sesuai dengan instruksi yang diberikan }\end{array}$ & 5 \\
\hline
\end{tabular}

Kriteria tanggung jawab terdiri dari 5 sub kriteria penilaian, dimana masing-masing sub kriteria mempunyai nilai bobot dimulai dari 1 sampai 5. Apabila penilaian semakin baik dan bagus maka nilai bobot yang didapatkan juga semakin besar.

D. Kriteria Kerjasama (C4)

Kriteria kerjasama merupakan kemampuan karyawan dalam berkolaborasi dengan rekan-rekan kerjanya untuk menyelesaikan borongan pekerjaan dengan hasil yang lebih baik. Suatu pekerjaan apabila dilakukan bersama-sama atau saling membantu satu sama lainnya dapat menyelesaikan pekerjaan dengan cepat dan mudah sehingga tujuan dapat dicapai. 
Tabel 6. Komposisi Kriteria Kerjasama

\begin{tabular}{|c|c|c|}
\hline Kriteria & Sub Kriteria & Nilai \\
\hline \multirow{3}{*}{ Kerjasama } & Tidak dapat bekerjasama & 1 \\
\cline { 2 - 3 } & Kurang dapat bekerjasama & 2 \\
\cline { 2 - 3 } & Dapat bekerjasama & 3 \\
\hline
\end{tabular}

Kriteria kerjasama terdiri dari 4 sub kriteria penilaian, dimana masing-masing sub kriteria mempunyai nilai bobot, dimulai dari 1 sampai 4. Apabila penilaian kerjasama seorang karyawan semakin baik dan bagus maka nilai bobot yang didapatkan juga semakin besar.

E. Kriteria Kejujuran (C5)

Kriteria kejujuran adalah penilaian kinerja karyawan terhadap kejujuran hasil jahitan sesuai dengan permintaan pelanggan, misalnya pola pakaian, ukuran dan jumlah pakaian yang telah ditentukan hasilnya sesuai dengan keinginan pelanggan.

Tabel 7. Komposisi Kriteria Kejujuran

\begin{tabular}{|c|l|c|}
\hline Kriteria & \multicolumn{1}{|c|}{ Sub Kriteria } & Nilai \\
\hline \multirow{4}{*}{ Kejujuran } & Tidak jujur & 1 \\
\cline { 2 - 3 } & Kurang jujur & 2 \\
\cline { 2 - 3 } & Jujur & 3 \\
\cline { 2 - 3 } & Sangat jujur & 4 \\
\hline
\end{tabular}

Kriteria kejujuran terdiri dari 4 sub kriteria penilaian. Dimana masing-masing sub kriteria mempunyai nilai bobot. dimulai dari 1 sampai 4. Apabila penilaian kejujuran seorang karyawan semakin baik dan bagus maka nilai bobot yang didapatkan juga semakin besar.

F. Kriteria Masa Kerja (C6)

Kriteria masa kerja merupakan perhitungan sejak adanya hubungan kerja antara pekerja dan pengusaha atau sejak pekerja pertama kali mulai bekerja di perusahaan tertentu berdasarkan pada Perjanjian Kerja.

Tabel 8. Komposisi Kriteria Masa Kerja

\begin{tabular}{clc}
\hline Kriteria & \multicolumn{1}{c}{ Sub Kriteria } & Nilai \\
\hline \multirow{3}{*}{ Masa Kerja } & Hitungan Bulan $<1$ tahun & 1 \\
& 1-3 tahun & 2 \\
& $3-5$ tahun & 3 \\
& $>5$ tahun & 4 \\
\hline
\end{tabular}


Kriteria masa kerja terdiri dari 4 sub kriteria penilaian. Dimana masing-masing sub kriteria mempunyai nilai bobot. dimulai dari 1 sampai 4. Apabila masa kerja seorang karyawan semakin lama dalam hitungan tahun, maka nilai bobot yang didapatkan juga semakin besar.

G. Kriteria Target Borongan (C7)

Kriteria Target Borongan adalah penilaian pencapaian jumlah target borongan yang sudah ditetapkan pada masing-masing karyawan dalam kurun waktu tertentu. Pencapaian jumlah target borongan juga perlu diperhatikan kualitas jahitan yang dihasilkan sangat bagus.

Tabel 9. Komposisi Kiriteria Target Borongan

\begin{tabular}{clc}
\hline Kriteria & \multicolumn{1}{c}{ Sub Kriteria } & Nilai \\
\hline \multirow{3}{*}{ Target Borongan } & Tidak tercapai & 1 \\
& Kurang tercapai & 2 \\
& Tercapai & 3 \\
& Sangat tercapai & 4 \\
\hline
\end{tabular}

Kriteria target borongan terdiri dari 4 sub kriteria penilaian. Dimana masing-masing sub kriteria mempunyai nilai bobot. dimulai dari 1 sampai 4. Apabila target borongan yang dicapai oleh karyawan semakin baik, maka nilai bobot yang didapatkan juga semakin besar.

H. Kriteria Kerapian Jahitan (C8)

Kriteria kerapian jahitan merupakan penilaian ketelitian karyawan dalam menjahit pakaian, dimana pakaian dengan jahitan rapi dan kuat mencerminkan seorang karyawan yang sudah berpengalaman dan mempunyai skill yang baik.

Tabel 10. Komposisi Kiriteria Kerapian Jahitan

\begin{tabular}{clc}
\hline Kriteri & \multicolumn{1}{c}{ Sub Kriteria } & Nilai \\
\hline \multirow{4}{*}{ Kerapian Jahitan } & Tidak Rapi & 1 \\
& Kurang Rapi & 2 \\
& Rapi & 3 \\
& Sangat Rapi & 4 \\
\hline
\end{tabular}

Kriteria kerapian jahitan terdiri dari 4 sub kriteria penilaian. Dimana masing-masing sub kriteria mempunyai nilai bobot. dimulai dari 1 sampai 4. Apabila kerapian jahitan semakin bagus, maka nilai bobot yang didapatkan juga semakin besar.

I. Kriteria Komunikasi (C9)

Kriteria komunikasi adalah penilaian soft skill karyawan dalam berkomunikasi dengan pimpinan, pelanggan, dan sesama karyawan. Komunikasi yang baik akan membuat orang disekitarnya menjadi nyaman dan tentram.

Tabel 11. Komposisi Kiriteria Komunikasi

\begin{tabular}{clc}
\hline Kriteria & \multicolumn{1}{c}{ Sub Kriteria } & Nilai \\
\hline \multirow{4}{*}{ Komunikasi } & Tidak Bagus & 1 \\
& Kurang Bagus & 2 \\
& Bagus & 3 \\
& Sangat Bagus & 4 \\
\hline
\end{tabular}


Kriteria komunikasi terdiri dari 4 sub kriteria penilaian. Dimana masing-masing sub kriteria mempunyai nilai bobot. dimulai dari 1 sampai 4. Apabila komunikasi karyawan semakin bagus, maka nilai bobot yang didapatkan juga semakin besar.

J. Kriteria Kepribadian (C10)

Kriteria kepribadian adalah penilaian akhlak dan sikap seorang karyawan dalam bekerja, bermasyarakat, dan beragama. Karyawan yang mempunyai kepribadian yang sangat baik dan penyantun akan disenangi oleh semua orang.

Tabel 12. Komposisi Kepribadian

\begin{tabular}{clc}
\hline Kriteria & \multicolumn{1}{c}{ Sub Kriteria } & Nilai \\
\hline \multirow{4}{*}{ Kepribadian } & Tidak Baik & 1 \\
& Kurang Baik & 2 \\
& Baik & 3 \\
& Sangat Baik & 4 \\
\hline
\end{tabular}

Kriteria kepribadian terdiri dari 4 sub kriteria penilaian. Dimana masing-masing sub kriteria mempunyai nilai bobot. dimulai dari 1 sampai 4. Apabila kepribadian karyawan semakin baik, maka nilai bobot yang didapatkan juga semakin besar.

\section{Membuat Rating Kecocokan Pada Alternatif}

Dari tabel 10 diatas, maka dilakukan konversi data berdasarkan nilai rating kriteria kecocokan, yaitu pada tabel 11 berikut ini:

Tabel 13. Nilai Rating Kecocokan Dari Alternatif

\begin{tabular}{lcccccccccc}
\hline \multicolumn{1}{c}{ Alternatif } & C1 & C2 & C3 & C4 & C5 & C6 & C7 & C8 & C9 & C10 \\
\hline Wawan Afrianto (A1) & 3 & 4 & 4 & 4 & 5 & 4 & 2 & 4 & 3 & 4 \\
Jupriadi (A2) & 5 & 3 & 5 & 3 & 4 & 2 & 3 & 4 & 3 & 3 \\
Musdar Effendi (A3) & 5 & 2 & 3 & 4 & 3 & 1 & 3 & 3 & 4 & 3 \\
Masrul (A4) & 4 & 5 & 2 & 4 & 3 & 3 & 4 & 2 & 2 & 4 \\
Maswanto (A5) & 2 & 4 & 3 & 2 & 4 & 3 & 2 & 3 & 3 & 3
\end{tabular}

Berdasarkan tabel nilai rating kecocokan alternatif diatas, maka membentuk matriks keputusan yang disebut dengan matrik $\mathrm{x}$.

$$
X=\left[\begin{array}{llllllllll}
3 & 4 & 4 & 4 & 5 & 4 & 2 & 4 & 3 & 4 \\
5 & 3 & 5 & 3 & 4 & 2 & 3 & 4 & 3 & 3 \\
5 & 2 & 3 & 4 & 3 & 1 & 3 & 3 & 4 & 3 \\
4 & 5 & 2 & 4 & 3 & 3 & 4 & 2 & 2 & 4 \\
2 & 4 & 3 & 2 & 4 & 3 & 2 & 3 & 3 & 3
\end{array}\right]
$$

Langkah 1: Normalisasi matriks keputusan menggunakan persamaan (1)

$$
\begin{aligned}
& r 11=\frac{3}{\sqrt{3^{2}+5^{2}+5^{2}+4^{2}+2^{2}}}=\frac{3}{\sqrt{9+25+25+16+4}}=\frac{3}{\sqrt{79}}=\frac{3}{8,8882}=0,3375 \\
& r 21=\frac{5}{\sqrt{3^{2}+5^{2}+5^{2}+4^{2}+2^{2}}}=\frac{5}{\sqrt{9+25+25+16+4}}=\frac{5}{\sqrt{79}}=\frac{5}{8,8882}=0,5625 \\
& r 31=\frac{5}{\sqrt{3^{2}+5^{2}+5^{2}+4^{2}+2^{2}}}=\frac{5}{\sqrt{9+25+25+16+4}}=\frac{5}{\sqrt{79}}=\frac{5}{8,8882}=0,3375 \\
& r 41=\frac{4}{\sqrt{3^{2}+5^{2}+5^{2}+4^{2}+2^{2}}}=\frac{4}{\sqrt{9+25+25+16+4}}=\frac{4}{\sqrt{79}}=\frac{4}{8,8882}=0,4500 \\
& r 51=\frac{2}{\sqrt{3^{2}+5^{2}+5^{2}+4^{2}+2^{2}}}=\frac{2}{\sqrt{9+25+25+16+4}}=\frac{2}{\sqrt{79}}=\frac{2}{8,8882}=0,9001
\end{aligned}
$$




$$
\begin{aligned}
& r 12=\frac{4}{\sqrt{4^{2}+3^{2}+2^{2}+5^{2}+4^{2}}}=\frac{4}{\sqrt{16+9+4+25+16}}=\frac{4}{\sqrt{70}}=\frac{4}{8,3666}=0,4781 \\
& r 22=\frac{3}{\sqrt{4^{2}+3^{2}+2^{2}+5^{2}+4^{2}}}=\frac{3}{\sqrt{16+9+4+25+16}}=\frac{3}{\sqrt{70}}=\frac{3}{8,3666}=0,3586 \\
& r 32=\frac{2}{\sqrt{4^{2}+3^{2}+2^{2}+5^{2}+4^{2}}}=\frac{2}{\sqrt{16+9+4+25+16}}=\frac{2}{\sqrt{70}}=\frac{2}{8,3666}=0,2390 \\
& r 42=\frac{5}{\sqrt{4^{2}+3^{2}+2^{2}+5^{2}+4^{2}}}=\frac{5}{\sqrt{16+9+4+25+16}}=\frac{5}{\sqrt{70}}=\frac{5}{8,3666}=0,5976 \\
& r 52=\frac{4}{\sqrt{4^{2}+3^{2}+2^{2}+5^{2}+4^{2}}}=\frac{4}{\sqrt{16+9+4+25+16}}=\frac{4}{\sqrt{70}}=\frac{4}{8,3666}=0,4781 \\
& r 13=\frac{4}{\sqrt{4^{2}+5^{2}+3^{2}+2^{2}+3^{2}}}=\frac{4}{\sqrt{16+25+9+4+9}}=\frac{4}{\sqrt{63}}=\frac{4}{7,9373}=0,5040 \\
& r 23=\frac{5}{\sqrt{4^{2}+5^{2}+3^{2}+2^{2}+3^{2}}}=\frac{5}{\sqrt{16+25+9+4+9}}=\frac{5}{\sqrt{63}}=\frac{5}{7,9373}=0,6299 \\
& r 33=\frac{3}{\sqrt{4^{2}+5^{2}+3^{2}+2^{2}+3^{2}}}=\frac{3}{\sqrt{16+25+9+4+9}}=\frac{3}{\sqrt{63}}=\frac{3}{7,9373}=0,3780 \\
& r 43=\frac{2}{\sqrt{4^{2}+5^{2}+3^{2}+2^{2}+3^{2}}}=\frac{2}{\sqrt{16+25+9+4+9}}=\frac{2}{\sqrt{63}}=\frac{2}{7,9373}=0,2520 \\
& r 53=\frac{3}{\sqrt{4^{2}+5^{2}+3^{2}+2^{2}+3^{2}}}=\frac{3}{\sqrt{16+25+9+4+9}}=\frac{3}{\sqrt{63}}=\frac{3}{7,9373}=0,3780 \\
& r 14=\frac{4}{\sqrt{4^{2}+3^{2}+4^{2}+4^{2}+2^{2}}}=\frac{4}{\sqrt{16+9+16+16+4}}=\frac{4}{\sqrt{61}}=\frac{4}{7,8102}=0,5121 \\
& r 24=\frac{3}{\sqrt{4^{2}+3^{2}+4^{2}+4^{2}+2^{2}}}=\frac{3}{\sqrt{16+9+16+16+4}}=\frac{3}{\sqrt{61}}=\frac{3}{7,8102}=0,3841 \\
& r 34=\frac{4}{\sqrt{4^{2}+3^{2}+4^{2}+4^{2}+2^{2}}}=\frac{4}{\sqrt{16+9+16+16+4}}=\frac{4}{\sqrt{61}}=\frac{4}{7,8102}=0,5121 \\
& r 44=\frac{4}{\sqrt{4^{2}+3^{2}+4^{2}+4^{2}+2^{2}}}=\frac{4}{\sqrt{16+9+16+16+4}}=\frac{4}{\sqrt{61}}=\frac{4}{7,8102}=0,5121 \\
& r 54=\frac{2}{\sqrt{4^{2}+3^{2}+4^{2}+4^{2}+2^{2}}}=\frac{2}{\sqrt{16+9+16+16+4}}=\frac{2}{\sqrt{61}}=\frac{2}{7,8102}=0,2561 \\
& r 15=\frac{5}{\sqrt{5^{2}+4^{2}+3^{2}+3^{2}+4^{2}}}=\frac{5}{\sqrt{25+16+9+9+16}}=\frac{5}{\sqrt{75}}=\frac{5}{8,6603}=0,5774 \\
& r 25=\frac{4}{\sqrt{5^{2}+4^{2}+3^{2}+3^{2}+4^{2}}}=\frac{4}{\sqrt{25+16+9+9+16}}=\frac{4}{\sqrt{75}}=\frac{4}{8,6603}=0,4619 \\
& r 35=\frac{3}{\sqrt{5^{2}+4^{2}+3^{2}+3^{2}+4^{2}}}=\frac{3}{\sqrt{25+16+9+9+16}}=\frac{3}{\sqrt{75}}=\frac{3}{8,6603}=0,3464 \\
& \begin{array}{l}
r 45=\frac{3}{\sqrt{5^{2}+4^{2}+3^{2}+3^{2}+4^{2}}}=\frac{4}{\sqrt{25+16+9+9+16}}=\frac{3}{\sqrt{75}}=\frac{3}{8,6603}=0,3464 \\
r 55=\frac{4}{\sqrt{5^{2}+4^{2}+3^{2}+3^{2}+4^{2}}}=\frac{4}{\sqrt{25+16+9+9+16}}=\frac{4}{\sqrt{75}}=\frac{4}{8,6603}=0,4619
\end{array}
\end{aligned}
$$

Untuk menentukan nilai rating normalisasi berikutnya, sampai pada r710 menggunakan cara yang sama diatas. Hasil perhitungan rating normalisasi diatas dapat dilihat pada matrik normalisasi berikut ini:

$$
R=\left[\begin{array}{llllllllll}
0,3375 & 0,4781 & 0,5040 & 0,5121 & 0,5774 & 0,6405 & 0,3086 & 0,5443 & 0,4376 & 0,5208 \\
0,5625 & 0,3586 & 0,6299 & 0,3841 & 0,4619 & 0,3203 & 0,4629 & 0,5443 & 0,4376 & 0,3906 \\
0,5625 & 0,2390 & 0,3780 & 0,5121 & 0,3464 & 0,1601 & 0,4629 & 0,4082 & 0,5835 & 0,3906 \\
0,4500 & 0,5976 & 0,2520 & 0,5121 & 0,3464 & 0,4804 & 0,6172 & 0,2722 & 0,2917 & 0,5208 \\
0,2250 & 0,4781 & 0,3780 & 0,2561 & 0,4619 & 0,4804 & 0,3086 & 0,4082 & 0,4376 & 0,3906
\end{array}\right]
$$


Langkah 2: Memberikan nilai bobot pada matriks yang telah dinormalisasi Menggunakan Rumus : $\mathrm{V}_{\mathrm{ij}}=\mathrm{r}_{\mathrm{ij}} \cdot \mathrm{w}_{\mathrm{j}}$
$\mathrm{V} 11=0,3375 \times 4=1,3501$
$\mathrm{V} 16=0,6405 \times 2=1,2810$
$\mathrm{V} 21=0,5625 \times 4=2,2502$
$\mathrm{V} 26=0,3203 \times 2=0,6405$
$\mathrm{V} 31=0,5625 \times 4=2,2502$
$\mathrm{V} 36=0,1601 \times 2=0,3203$
$\mathrm{V} 41=0,4500 \times 4=1,8001$
$\mathrm{V} 46=0,4804 \times 2=0,9608$
$\mathrm{V} 51=0,2250 \times 4=0,9001$
$\mathrm{V} 56=0,4804 \times 2=0,9608$
$\mathrm{V} 12=0,4781 \times 3=1,4343$
$\mathrm{V} 17=0,3086 \times 5=1,5430$
$\mathrm{V} 22=0,3586 \times 3=1,0757$
$\mathrm{V} 27=0,4629 \times 5=2,3146$
$\mathrm{V} 32=0,2390 \times 3=0,7171$
$\mathrm{V} 37=0,4629 \times 5=2,3146$
$\mathrm{V} 42=0,5976 \times 3=1,7928$
$\mathrm{V} 47=0,6172 \times 5=3,0861$
$\mathrm{V} 52=0,4781 \times 3=1,4343$
$\mathrm{V} 57=0,3086 \times 5=1,5430$
$\mathrm{V} 13=0,5040 \times 5=2,5198$
$\mathrm{V} 18=0,5443 \times 4=2,1773$
$\mathrm{V} 23=0,6299 \times 5=3,1497$
$\mathrm{V} 28=0,5443 \times 4=2,1773$
$\mathrm{V} 33=0,3780 \times 5=1,8898$
$\mathrm{V} 38=0,4082 \times 4=1,6330$
$\mathrm{V} 43=0,2520 \times 5=1,2599$
$\mathrm{V} 48=0,2722 \times 4=1,0887$
$\mathrm{V} 53=0,3780 \times 5=1,8898$
$\mathrm{V} 58=0,4082 \times 4=1,6330$
$\mathrm{V} 14=0,5121 \times 2=1,0243$
$\mathrm{V} 19=0,4376 \times 2=0,8752$
$\mathrm{V} 24=0,3841 \times 2=0,7682$
$\mathrm{V} 29=0,4376 \times 2=0,8752$
$\mathrm{V} 34=0,5121 \times 2=1,0243$
$\mathrm{V} 39=0,5835 \times 2=1,1669$
$\mathrm{V} 44=0,5121 \times 2=1,0243$
$\mathrm{V} 49=0,2917 \times 2=0,5835$
$\mathrm{V} 54=0,2561 \times 2=0,5121$
$\mathrm{V} 59=0,4376 \times 2=0,8752$
$\mathrm{V} 15=0,5774 \times 4=2,3094$
$\mathrm{V} 110=0,5208 \times 5=2,6038$
$\mathrm{V} 25=0,4619 \times 4=1,8475$
$\mathrm{V} 210=0,3906 \times 5=1,9528$
$\mathrm{V} 35=0,3464 \times 4=1,3856$
$\mathrm{V} 310=0,3906 \times 5=1,9528$
$\mathrm{V} 45=0,3464 \times 4=1,3856$
$\mathrm{V} 410=0,5208 \times 5=2,6038$
$\mathrm{V} 55=0,4619 \times 4=1,8475$
$\mathrm{V} 510=0,3906 \times 5=1,9528$

Hasil perhitungan nilai rating preferensi diatas dapat dilihat pada matrik preferensi berikut ini:

$V=\left[\begin{array}{llllllllll}1,3501 & 1,4343 & 2,5198 & 1,0243 & 2,3094 & 1,2810 & 1,5430 & 2,1773 & 0,8752 & 2,6038 \\ 2,2502 & 1,0757 & 3,1497 & 0,7682 & 1,8475 & 0,6405 & 2,3146 & 2,1773 & 0,8752 & 1,9528 \\ 2,2502 & 0,7171 & 1,8898 & 1,0243 & 1,3856 & 0,3203 & 2,3146 & 1,6330 & 1,1669 & 1,9528 \\ 1,8001 & 1,7928 & 1,2599 & 1,0243 & 1,3856 & 0,9608 & 3,0861 & 1,0887 & 0,5835 & 2,6038 \\ 0,9001 & 1,4343 & 1,8898 & 0,5121 & 1,8475 & 0,9608 & 1,5430 & 1,6330 & 0,8752 & 1,9528\end{array}\right]$

Langkah 3 : Menentukan himpunan concordance dan discordance index untuk setiap pasang dari alternative, perhatikan persamaan (3).

1) Himpunan Concordance

$$
\begin{aligned}
& \mathrm{C}_{12}=\{\mathrm{j}, \mathrm{v} 1 \mathrm{j} \geq \mathrm{v} 2\}=\{2,4,5,6,8,9,10\} \\
& \mathrm{C}_{13}=\{\mathrm{j}, \mathrm{v} 1 \mathrm{j} \geq \mathrm{v} 3\}=\{2,3,4,5,6,8,10\} \\
& \mathrm{C}_{14}=\{\mathrm{j}, \mathrm{v} 1 \mathrm{j} \geq \mathrm{v} 4\}=\{3,4,5,6,8,9,10\} \\
& \mathrm{C}_{15}=\{\mathrm{j}, \mathrm{v} 1 \mathrm{j} \geq \mathrm{v} 5\}=\{1,2,3,4,5,6,7,8,9,10\} \\
& \mathrm{C}_{21}=\{\mathrm{j}, \mathrm{v} 2 \mathrm{j} \geq \mathrm{v} 1\}=\{1,3,7,8,9\} \\
& \mathrm{C}_{23}=\{\mathrm{j}, \mathrm{v} 2 \mathrm{j} \geq \mathrm{v} 3\}=\{1,2,3,5,6,7,8,10\}
\end{aligned}
$$




$$
\begin{aligned}
& \mathrm{C}_{24}=\{\mathrm{j}, \mathrm{v} 2 \mathrm{j} \geq \mathrm{v} 4\}=\{1,3,5,8,9\} \\
& \mathrm{C}_{25}=\{\mathrm{j}, \mathrm{v} 2 \mathrm{j} \geq \mathrm{v} 5\}=\{1,3,4,5,7,8,9,10\} \\
& \mathrm{C}_{31}=\{\mathrm{j}, \mathrm{v} 3 \mathrm{j} \geq \mathrm{v} 1\}=\{1,4,7,9\} \\
& \mathrm{C}_{32}=\{\mathrm{j}, \mathrm{v} 3 \mathrm{j} \geq \mathrm{v} 2\}=\{1,4,7,9,10\} \\
& \mathrm{C}_{34}=\{\mathrm{j}, \mathrm{v} 3 \mathrm{j} \geq \mathrm{v} 4\}=\{1,3,4,5,8,9\} \\
& \mathrm{C}_{35}=\{\mathrm{j}, \mathrm{v} 3 \mathrm{j} \geq \mathrm{v} 5\}=\{1,3,4,7,8,9,10\} \\
& \mathrm{C}_{41}=\{\mathrm{j}, \mathrm{v} 4 \mathrm{j} \geq \mathrm{v} 1\}=\{1,2,4,7,10\} \\
& \mathrm{C}_{42}=\{\mathrm{j}, \mathrm{v} 4 \mathrm{j} \geq \mathrm{v} 2\}=\{2,4,6,7,10\} \\
& \mathrm{C}_{43}=\{\mathrm{j}, \mathrm{v} 4 \mathrm{j} \geq \mathrm{v} 3\}=\{2,4,5,6,7,10\} \\
& \mathrm{C}_{45}=\{\mathrm{j}, \mathrm{v} 4 \mathrm{j} \geq \mathrm{v} 5\}=\{1,2,4,6,7,10\} \\
& \mathrm{C}_{51}=\{\mathrm{j}, \mathrm{v} 5 \mathrm{j} \geq \mathrm{v} 1\}=\{2,7,9\} \\
& \mathrm{C}_{52}=\{\mathrm{j}, \mathrm{v} 5 \mathrm{j} \geq \mathrm{v} 2\}=\{2,5,6,9,10\} \\
& \mathrm{C}_{53}=\{\mathrm{j}, \mathrm{v} 5 \mathrm{j} \geq \mathrm{v} 3\}=\{2,3,5,6,8,10\} \\
& \mathrm{C}_{54}=\{\mathrm{j}, \mathrm{v} 5 \mathrm{j} \geq \mathrm{v} 4\}=\{3,5,6,8,9\}
\end{aligned}
$$

2) Himpunan Discordance

$$
\begin{aligned}
& \mathrm{D}_{12}=\{\mathrm{j}, \mathrm{v} 1 \mathrm{j}<\mathrm{v} 2\}=\{1,3,7\} \\
& \mathrm{D}_{13}=\{\mathrm{j}, \mathrm{v} 1 \mathrm{j}<\mathrm{v} 3\}=\{1,7,9\} \\
& \mathrm{D}_{14}=\{\mathrm{j}, \mathrm{v} 1 \mathrm{j}<\mathrm{v} 4\}=\{1,2,7\} \\
& \mathrm{D}_{15}=\{\mathrm{j}, \mathrm{v} 1 \mathrm{j} \geq \mathrm{v} 5\}=\{\} \\
& \mathrm{D}_{21}=\{\mathrm{j}, \mathrm{v} 2 \mathrm{j}<\mathrm{v} 1\}=\{2,4,5,6,10\} \\
& \mathrm{D}_{23}=\{\mathrm{j}, \mathrm{v} 2 \mathrm{j}<\mathrm{v} 3\}=\{4,9\} \\
& \mathrm{D}_{24}=\{\mathrm{j}, \mathrm{v} 2 \mathrm{j}<\mathrm{v} 4\}=\{2,4,6,7,10\} \\
& \mathrm{D}_{25}=\{\mathrm{j}, \mathrm{v} 2 \mathrm{j}<\mathrm{v} 5\}=\{2,6\} \\
& \mathrm{D}_{31}=\{\mathrm{j}, \mathrm{v} 3 \mathrm{j}<\mathrm{v} 1\}=\{2,3,5,6,8,10\} \\
& \mathrm{D}_{32}=\{\mathrm{j}, \mathrm{v} 3 \mathrm{j}<\mathrm{v} 2\}=\{2,3,5,6,8\} \\
& \mathrm{D}_{34}=\{\mathrm{j}, \mathrm{v} 3 \mathrm{j}<\mathrm{v} 4\}=\{2,6,7,10\} \\
& \mathrm{D}_{35}=\{\mathrm{j}, \mathrm{v} 3 \mathrm{j}<\mathrm{v} 5\}=\{2,5,6\} \\
& \mathrm{D}_{41}=\{\mathrm{j}, \mathrm{v} 4 \mathrm{j}<\mathrm{v} 1\}=\{3,5,6,8,9\} \\
& \mathrm{D}_{42}=\{\mathrm{j}, \mathrm{v} 4 \mathrm{j}<\mathrm{v} 2\}=\{1,3,5,8,9\} \\
& \mathrm{D}_{43}=\{\mathrm{j}, \mathrm{v} 4 \mathrm{j}<\mathrm{v} 3\}=\{1,3,8,9\} \\
& \mathrm{D}_{45}=\{\mathrm{j}, \mathrm{v} 4 \mathrm{j}<\mathrm{v} 5\}=\{3,5,8,9\} \\
& \mathrm{D}_{51}=\{\mathrm{j}, \mathrm{v} 5 \mathrm{j}<\mathrm{v} 1\}=\{1,3,4,5,6,8,10\} \\
& \mathrm{D}_{52}=\{\mathrm{j}, \mathrm{v} 5 \mathrm{j}<\mathrm{v} 2\}=\{1,3,4,7,8\} \\
& \mathrm{D}_{53}=\{\mathrm{j}, \mathrm{v} 5 \mathrm{j} \geq \mathrm{v} 3\}=\{1,4,7,9\} \\
& \mathrm{D}_{54}=\{\mathrm{j}, \mathrm{v} 5 \mathrm{j} \geq \mathrm{v} 4\}=\{1,2,4,7,10\}
\end{aligned}
$$

Langkah 4 : Menentukan matriks concordance dan discordance, perhatikan persamaan (4).

1) Matriks Concordance, menggunakan persamaan 4a.

$$
\begin{aligned}
& \mathrm{C}_{12}=\mathrm{W} 2+\mathrm{W} 4+\mathrm{W} 5+\mathrm{W} 6+\mathrm{W} 8+\mathrm{W} 9+\mathrm{W} 10=3+5+2+4+2+4+2=22 \\
& \mathrm{C}_{13}=\mathrm{W} 2+\mathrm{W} 3+\mathrm{W} 4+\mathrm{W} 5+\mathrm{W} 6+\mathrm{W} 8+\mathrm{W} 10=3+5+2+4+2+4+5=25 \\
& \mathrm{C}_{14}=\mathrm{W} 3+\mathrm{W} 4+\mathrm{W} 5+\mathrm{W} 6+\mathrm{W} 8+\mathrm{W} 9+\mathrm{W} 10=5+2+4+2+4+2+5=24
\end{aligned}
$$




$$
\begin{aligned}
& \mathrm{C}_{15}= \mathrm{W} 1+\mathrm{W} 2+\mathrm{W} 3+\mathrm{W} 4+\mathrm{W} 5+\mathrm{W} 6+\mathrm{W} 7+\mathrm{W} 8+\mathrm{W} 9+\mathrm{W} 10=4+3+5+2+ \\
& 4+2+5+4+2+5=36 \\
& \mathrm{C}_{21}= \mathrm{W} 1+\mathrm{W} 3+\mathrm{W} 7+\mathrm{W} 8+\mathrm{W} 9=4+5+5+4+2=20 \\
& \mathrm{C}_{23}= \mathrm{W} 1+\mathrm{W} 2+\mathrm{W} 3+\mathrm{W} 5+\mathrm{W} 6+\mathrm{W} 7+\mathrm{W} 8+\mathrm{W} 10=4+3+5+4+2+5+4+ \\
& 5=32 \\
& \mathrm{C}_{24}= \mathrm{W} 1+\mathrm{W} 3+\mathrm{W} 5+\mathrm{W} 8+\mathrm{W} 9=4+5+4+4+2=19 \\
& \mathrm{C}_{25}=\mathrm{W} 1+\mathrm{W} 3+\mathrm{W} 4+\mathrm{W} 5+\mathrm{W} 7+\mathrm{W} 8+\mathrm{W} 9+\mathrm{W} 10=4+5+2+4+5+4+2+ 5 \\
&= 31 \\
& \mathrm{C}_{31}=\mathrm{W} 1+\mathrm{W} 4+\mathrm{W} 7+\mathrm{W} 9=4+2+5+2=13 \\
& \mathrm{C}_{32}=\mathrm{W} 2+\mathrm{W} 3+\mathrm{W} 5+\mathrm{W} 6+\mathrm{W} 8=3+5+4+2+4=18 \\
& \mathrm{C}_{34}=\mathrm{W} 1+\mathrm{W} 3+\mathrm{W} 4+\mathrm{W} 5+\mathrm{W} 8+\mathrm{W} 9=4+5+2+4+4+2=21 \\
& \mathrm{C}_{35}=\mathrm{W} 1+\mathrm{W} 3+\mathrm{W} 4+\mathrm{W} 7+\mathrm{W} 8+\mathrm{W} 9+\mathrm{W} 10=4+5+2+5+4+2+5=27 \\
& \mathrm{C}_{41}=\mathrm{W} 3+\mathrm{W} 5+\mathrm{W} 6+\mathrm{W} 8+\mathrm{W} 9=5+4+2+4+2=17 \\
& \mathrm{C}_{42}=\mathrm{W} 2+\mathrm{W} 4+\mathrm{W} 6+\mathrm{W} 7+\mathrm{W} 10=3+2+2+5+5=15 \\
& \mathrm{C}_{43}=\mathrm{W} 2+\mathrm{W} 4+\mathrm{W} 5+\mathrm{W} 6+\mathrm{W} 7+\mathrm{W} 10=3+2+4+2+5+5=21 \\
& \mathrm{C}_{45}=\mathrm{W} 1+\mathrm{W} 2+\mathrm{W} 4+\mathrm{W} 6+\mathrm{W} 7+\mathrm{W} 10=4+3+2+2+5+5=21 \\
& \mathrm{C}_{51}=\mathrm{W} 2+\mathrm{W} 7+\mathrm{W} 9=3+5+2=10 \\
& \mathrm{C}_{52}=\mathrm{W} 1+\mathrm{W} 3+\mathrm{W} 4+\mathrm{W} 7+\mathrm{W} 8=4+5+2+5+4=20 \\
& \mathrm{C}_{53}=\mathrm{W} 2+\mathrm{W} 3+\mathrm{W} 5+\mathrm{W} 6+\mathrm{W} 8+\mathrm{W} 10=3+5+4+2+4+5=23 \\
& \mathrm{C}_{54}=\mathrm{W} 1+\mathrm{W} 2+\mathrm{W} 4+\mathrm{W} 7+\mathrm{W} 10=4+3+2+5+5=19 \\
& \mathrm{M} 10
\end{aligned}
$$

Maka diperoleh matriks concordance sebagai berikut:

$$
C=\left[\begin{array}{ccccc}
- & 22 & 25 & 24 & 36 \\
20 & - & 32 & 19 & 31 \\
13 & 18 & - & 21 & 27 \\
17 & 15 & 21 & - & 21 \\
10 & 20 & 23 & 19 & -
\end{array}\right]
$$

2) Matriks Discordance, menggunakan persamaan $4 \mathrm{~b}$.

$$
D_{12}=\frac{\max \{|1,3501-2,2502| ;|2,5198-3,1497| ;|1,5430-2,3146|\}}{\max \{|1,3501-2,2502| ;|1,4343-1,0757| ;|2,5198-3,1497| ;|1,0243-0,7682| ;|2,3094-1,8475| ;}
$$

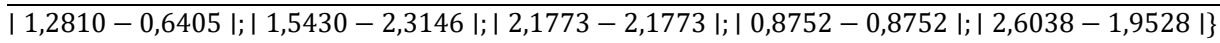

$=\frac{\max \{0,9001 ; 0,6299 ; 0,7715\}}{\max \{0,9001 ; 0,3586 ; 0,6299 ; 0,2561 ; 0,4619 ; 0,6405 ; 0,7715 ; 0 ; 0 ; 0,6509\}}=\frac{0,9001}{0,9001}=\mathbf{1}$

$D_{13}=\frac{\max \{|1,3501-2,2502| ;|1,5430-2,3146| ;|0,8752-0,8752|\}}{\max \{|1,3501-2,2502| ;|1,4343-0,7171| ;|2,5198-1,8898| ;|1,0243-1,0243| ;|2,3094-1,3856| ;}$

$\overline{|1,2810-0,3203| ;|1,5430-2,3146| ;|2,1773-1,6330| ;|0,8752-1,1669| ;|2,6038-1,9528|\}}$

$=\frac{\max \{0,9001 ; 0,6299 ; 0,7715\}}{\max \{0,9001 ; 0,7172 ; 0,6299 ; 0 ; 0,9238 ; 0,9608 ; 0,7715 ; 0,5443 ; 0,2917 ; 0,6509\}}=\frac{0,9001}{0,9608}=\mathbf{0}, \mathbf{9 3 6 8}$

$D_{14}=\frac{\max \{|1,3501-1,8001| ;|1,4343-1,7928| ;|1,5430-3,0861|\}}{\max \{|1,3501-1,8001| ;|1,4343-1,7928| ;|2,5198-1,2599| ;|1,0243-1,0243| ;|2,3094-1,3856| ;}$

$\overline{|1,2810-0,9608| ;|1,5430-3,0861| ; \mid 2,1773-1,0887 \text { |; | 0,8752-0,5835 |; | 2,6038-2,6038 |\} }}$ 


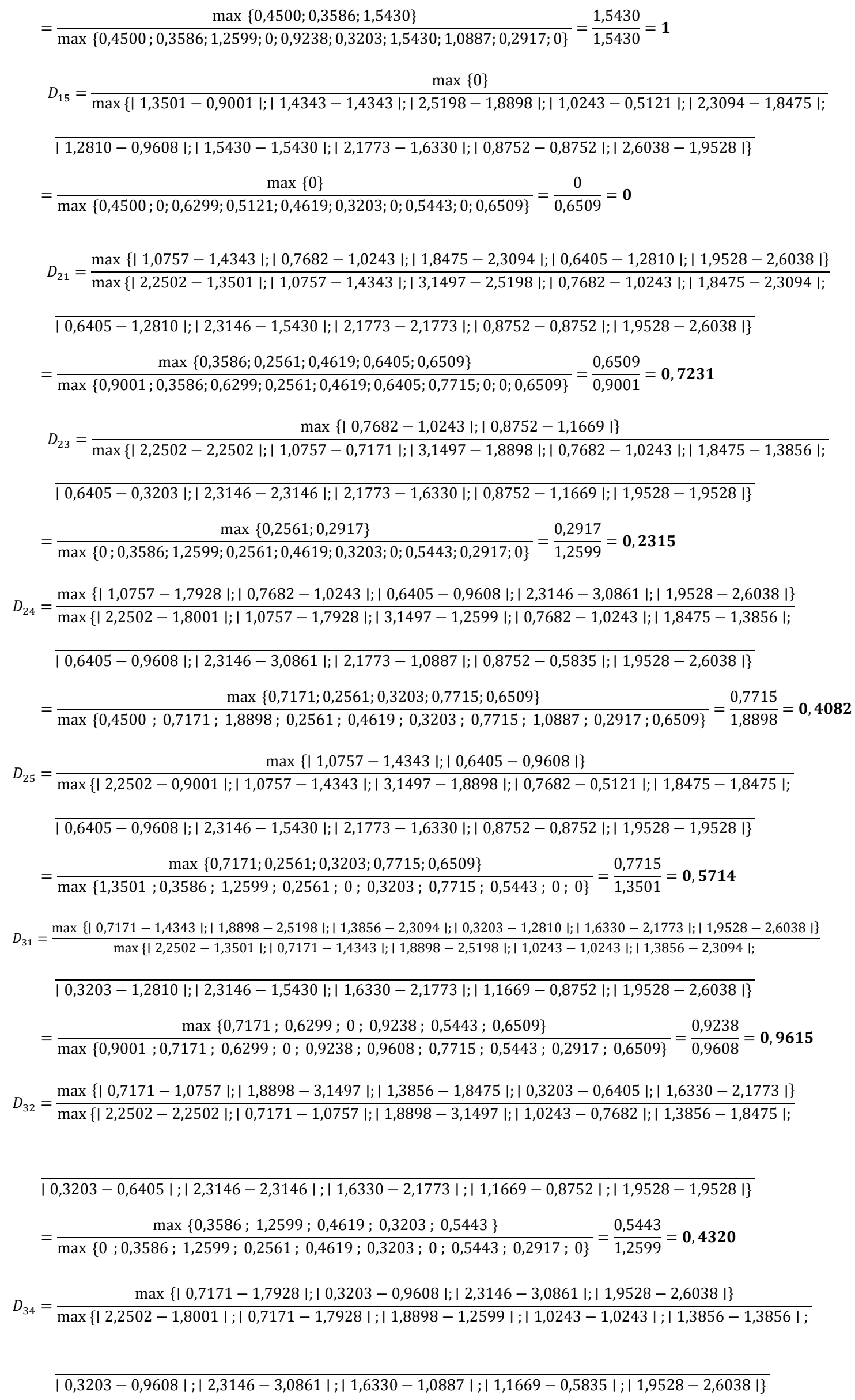




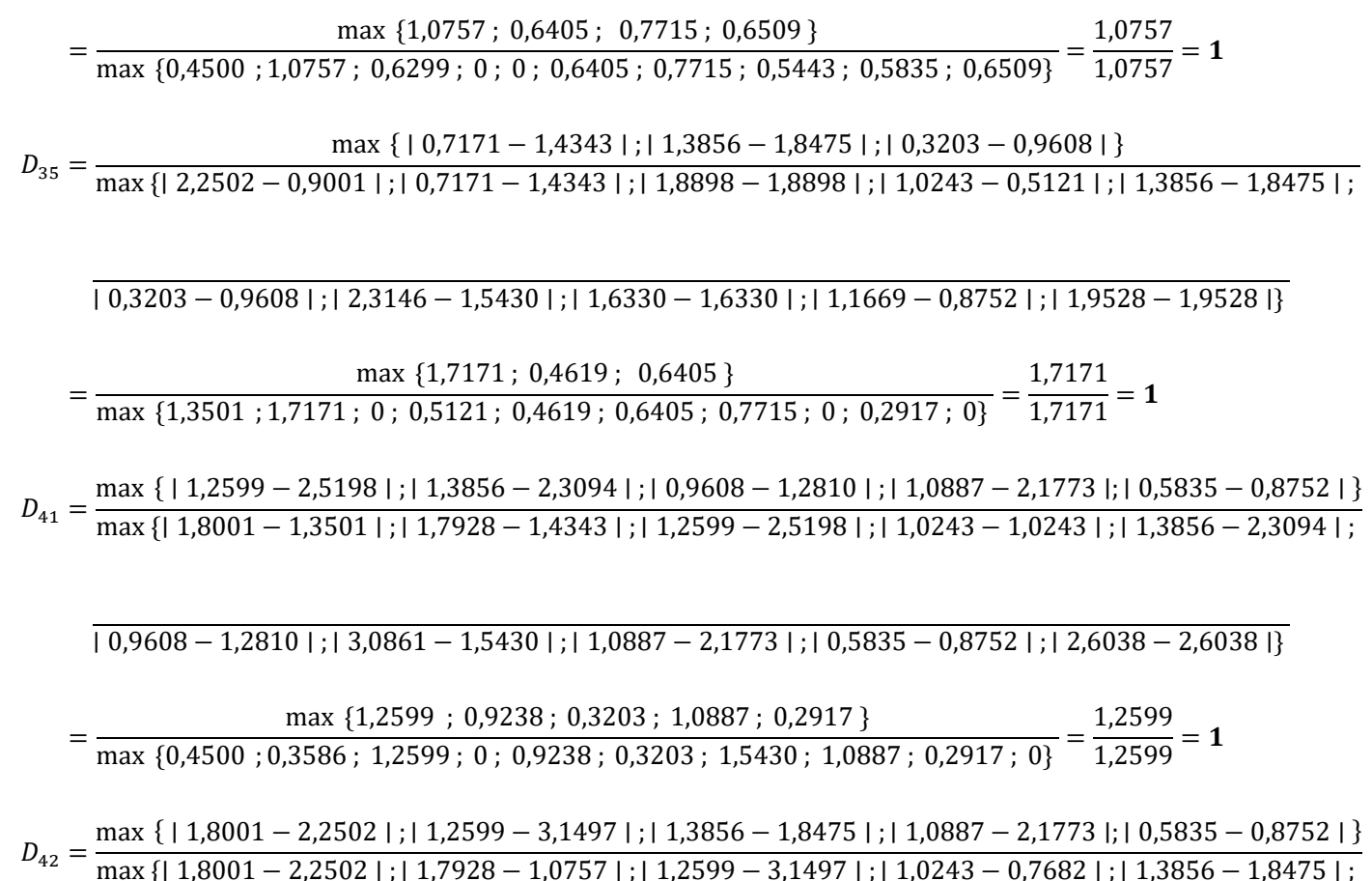




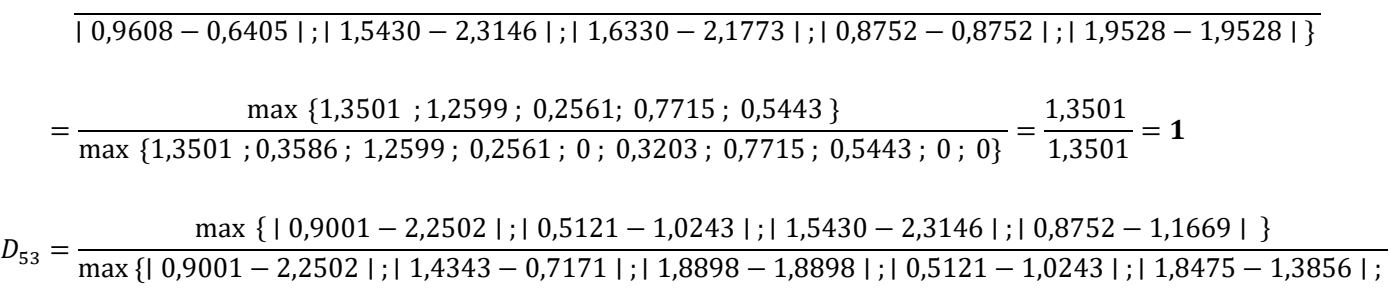

$\overline{|0,9608-0,3203| ;|1,5430-2,3146| ;|1,6330-1,6330| ;|0,8752-1,1669| ;|1,9528-1,9528|\}}$

$=\frac{\max \{1,3501 ; 0,5121 ; 0,7715 ; 0,2917\}}{\max \{1,3501 ; 0,7171 ; 0 ; 0,5121 ; 0,4619 ; 0,6405 ; 0,7715 ; 0 ; 0,2917 ; 0\}}=\frac{1,3501}{1,3501}=\mathbf{1}$

$D_{54}=\frac{\max \{|0,9001-1,8001| ;|1,4343-1,7928| ;|0,5121-1,0243| ;|1,5430-3,0861| ;|1,9528-2,6038|\}}{\max \{|0,9001-1,8001| ;|1,4343-1,7928| ;|1,8898-1,2599| ;|0,5121-1,0243| ;|1,8475-1,3856| ;}$

$\overline{|0,9608-0,9608| ;|1,5430-3,0861| ;|1,6330-1,0887| ;|0,8752-0,5835| ;|1,9528-2,6038|\}}$

$=\frac{\max \{0,9001 ; 0,3586 ; 0,5121 ; 1,5430 ; 0,6509\}}{\max \{0,9001 ; 0,3586 ; 0,6299 ; 0,5121 ; 0,4619 ; 0 ; 1,5430 ; 0,5443 ; 0,2917 ; 0,6509\}}=\frac{1,5430}{1,5430}=\mathbf{1}$

Maka diperoleh matriks discordance sebagai berikut:

$$
D=\left[\begin{array}{ccccc}
- & 1 & 0,9368 & 1 & 0 \\
0,7231 & - & 0,2315 & 0,4082 & 0,5714 \\
0,9615 & 0,4320 & - & 1 & 1 \\
1 & 1 & 0,5856 & - & 0,4082 \\
1 & 1 & 1 & 1 & -
\end{array}\right]
$$

Langkah 5 : Menentukan matriks dominan concordance dan discordance

1) Matriks dominan Concordance.

Menentukan nilai Treshold matriks dominan concordance menggunakan persamaan berikut:

$$
\begin{aligned}
\underline{C} & =\frac{\sum_{k=1}^{n} \sum_{l=1}^{n} c_{k l}}{m x(m-1)} \\
& =\frac{C 12+C 13+C 14+C 15+C 21+C 23+C 24+C 25+C 31+C 32+C 34+C 35+}{m x(m-1)} \\
& =\frac{241+C 42+C 43+C 45+C 51+C 52+C 53+C 54}{m x(5-1)} \\
& =\frac{434}{20}=21,7
\end{aligned}
$$

Nilai setiap elemen matriks $F$ diperoleh dengan menggunakan persamaan : $f_{k l}=1$, jika $\mathrm{c}_{\mathrm{kl}} \geq \underline{\mathrm{c}} \operatorname{dan} f_{k l}=0$, jika $\mathrm{c}_{\mathrm{kl}}<\underline{\mathrm{c}}$, adalah sebagai berikut: 


$$
F=\left[\begin{array}{ccccc}
- & 1 & 1 & 1 & 1 \\
0 & - & 1 & 0 & 1 \\
0 & 0 & - & 0 & 1 \\
0 & 0 & 0 & - & 0 \\
0 & 0 & 1 & 0 & -
\end{array}\right]
$$

2) Matriks dominan Discordance

Menentukan nilai Treshold matriks dominan discordance menggunakan persamaan berikut:

$$
\begin{aligned}
\underline{D}=\frac{\sum_{k=1}^{n} \sum_{l=1}^{n} c_{k l}}{m x(m-1)} & \\
= & \frac{D 12+D 13+D 14+D 15+D 21+D 23+D 24+D 25+D 31+D 32+D 34+D 35+}{D 41+D 42+D 43+D 45+D 51+D 52+D 53+D 54} \\
= & \frac{1+0,9368+1+0+0,7231+0,2315+0,4082+0,5714+0,9615+}{0,4320+1+1+1+1+0,5856+0,4082+1+1+1+1} \\
= & \frac{15,2583}{20}=0,7629
\end{aligned}
$$

Nilai setiap elemen matriks $G$ diperoleh dengan menggunakan persamaan : $g_{k l}=1$, jika $\mathrm{c}_{\mathrm{kl}} \geq \underline{\mathrm{c}}$ dan $g_{k l}=0$, jika $\mathrm{c}_{\mathrm{kl}}<\underline{\mathrm{c}}$, adalah sebagai berikut:

$$
G=\left[\begin{array}{ccccc}
- & 1 & 1 & 1 & 1 \\
0 & - & 0 & 0 & 0 \\
1 & 0 & - & 1 & 1 \\
1 & 1 & 0 & - & 0 \\
1 & 1 & 1 & 1 & -
\end{array}\right]
$$

Langkah 6 : Menentukan aggregate dominance matriks

Dalam menentukan aggregate dominance matriks dengan menggunakan persamaan berikut :

$$
\begin{gathered}
\boldsymbol{e}_{\mathrm{kl}}=\mathrm{f}_{\mathrm{kl}} \times \mathrm{g}_{\mathrm{kl}} \\
\boldsymbol{e}_{12}=f_{12} \times g_{12}=1 \times 1=1 \\
\boldsymbol{e}_{13}=f_{13} \times g_{13}=1 \times 1=1 \\
\boldsymbol{e}_{14}=f_{14} \times g_{14}=1 \times 1=1 \\
\boldsymbol{e}_{15}=f_{15} \times g_{15}=1 \times 1=1 \\
\boldsymbol{e}_{21}=f_{21} \times g_{21}=0 \times 0=0 \\
\boldsymbol{e}_{23}=f_{23} \times g_{23}=1 \times 0=0 \\
\boldsymbol{e}_{24}=f_{24} \times g_{24}=0 \times 0=0 \\
\boldsymbol{e}_{25}=f_{25} \times g_{25}=1 \times 0=0 \\
\boldsymbol{e}_{31}=f_{31} \times g_{31}=0 \times 1=0 \\
\boldsymbol{e}_{32}=f_{32} \times g_{32}=0 \times 0=0
\end{gathered}
$$




$$
\begin{aligned}
& \boldsymbol{e}_{34}=f_{34} \times g_{34}=0 \times 1=0 \\
& \boldsymbol{e}_{35}=f_{35} \times g_{35}=1 \times 1=1 \\
& \boldsymbol{e}_{41}=f_{41} \times g_{41}=0 \times 1=0 \\
& \boldsymbol{e}_{42}=f_{42} \times g_{42}=0 \times 1=0 \\
& \boldsymbol{e}_{43}=f_{43} \times g_{43}=0 \times 0=0 \\
& \boldsymbol{e}_{45}=f_{45} \times g_{45}=0 \times 0=0 \\
& \boldsymbol{e}_{51}=f_{51} \times g_{51}=0 \times 1=0 \\
& \boldsymbol{e}_{52}=f_{52} \times g_{52}=0 \times 1=0 \\
& \boldsymbol{e}_{53}=f_{53} \times g_{53}=1 \times 1=1 \\
& \boldsymbol{e}_{54}=f_{54} \times g_{54}=0 \times 1=0
\end{aligned}
$$

maka matriks $E$ adalah sebagai berikut:

$$
E=\left[\begin{array}{ccccc}
- & 1 & 1 & 1 & 1 \\
0 & - & 1 & 0 & 1 \\
0 & 0 & - & 0 & 1 \\
0 & 0 & 0 & - & 0 \\
0 & 0 & 1 & 0 & -
\end{array}\right]
$$

Langkah 7 : Mengeliminasi alternative (less favourable).

Tabel 14. Perangkingan

\begin{tabular}{ccc}
\hline Ranking & Alternatif & Jumlah Nilai \\
\hline 1 & A1 & 4 \\
2 & A3 & 1 \\
3 & A5 & 1 \\
4 & A2 & 0 \\
5 & A4 & 0 \\
\hline
\end{tabular}

Berdasarkan tabel perangkingan diatas, dapat dilihat secara berurutan dari total nilai tertinggi sampai nilai terendah, nilai tertinggi pada alternative A1 diikuti oleh A3 dan A5, sedangkan alternatif A2 dan A4 tereliminasi karena mempunyai jumlah nilai 0. Maka dapat disimpulkan bahwa penilaian kinerja karyawan terbaik pada Konveksi Sahabat adalah Wawan Afrianto (A1).

\section{SIMPULAN}

Kesimpulan yang dapat diambil dari penelitian ini adalah:

2. Dengan menggunakan metode Elimination Et Choix Traduisant La Realite (ELECTRE) dapat memudahkan Manajer Konveksi Sahabat dalam mengambil keputusan menilai kinerja karyawan terbaik.

3. Setelah menggunakan Metode Elimination Et Choix Traduisant La Realite dapat mengeliminasi nilai alternatif pada setiap kriteria.

4. Dengan menggunakan metode Elimination Et Choix Traduisant La Realite dapat menghasilkan keputusan dengan merangking nilai alternatif setiap kriteria.

5. Setelah melakukan perhitungan dengan metode Elimination Et Choix Traduisant La Realite, terdapat tiga dasar proses yaitu memilih, menyortir, dan memberikan peringkat. 


\section{B. Ucapan Terima Kasih}

Ucapan terima kasih kepada pihak-pihak yang telah memberikan dukungan terhadap penelitian.

\section{DAFTAR PUSTAKA}

[1] A. A. G. A. P. R. Asmara, "Implementasi Metode Simple Additive Weighting ( SAW ) Dalam Memprediksi Calon Mahasiswa Dropout STMIK STIKOM Bali," Sist. Inform., vol. 11, no. 1, pp. 11-18, 2016.

[2] F. Soemargono, "Kata Pengantar," Archipel, vol. 13, no. 1, pp. 15-20, 1977.

[3] R. K. Niswatin, "Sistem Seleksi Penerimaan Mahasiswa Baru Menggunakan Metode Weighted Product ( Wp )," Semin. Nas. Teknol. Inf. dan Multimed. 2016, pp. 31-36, 2016.

[4] F. Hadi, H. Syahputra, and I. Verdian, "Sistem Penunjang Keputusan Dalam Menentukan Calon Siswa Baru Pada Smk Negeri 1 Payakumbuh,” vol. 1, no. Senatkom, pp. 118-125, 2015.

[5] E. W. Perdani, "Sistem Pendukung Keputusan Penerimaan Siswa Baru Dengan Metode Simple Additive Weighting (SAW)," Edu Komputika J., vol. 1, no. 1, 2014.

[6] D. Guswandi, "Sistem Pendukung Keputusan Bantuan Bedah Rumah Menggunakan Metode Simple Additive Weighting Pada Badan Amil Zakat," Maj. Ilm. UPI YPTK Padang, vol. 24, no. 1, pp. 221-234, 2017.

[7] A. D. Susanti, M. Muslihudin, and S. Hartati, "Sistem Pendukung Keputusan Perankingan Calon Siswa Baru Jalur Undangan Menggunakan Simple Additive Weighting (Studi Kasus : Smk Bumi Nusantara Wonosobo)," Semnasteknomedia Online, vol. 5, no. 1, pp. 3-5-37, 2017.

[8] B. V. Christioko, J. T. Informasi, and N. Hidayati, "Henny Indriyawati," vol. 14, no. 2, pp. 82-85, 2017.

[9] M. N. Pratama, A. Sevtiana, and D. Martha, "Penerapan Metode Simple Additive Weighting (Saw) Pada Sistem Seleksi Penerimaan Calon Siswa Baru (Studi Kasus: Smk Negeri 1 Cirebon),” J. Digit, vol. 5, no. 2, pp. 159-170, 2017.

[10] A. Afshari, M. Mojahed, and R. Yusuff, "Simple additive weighting approach to personnel selection problem," Int. J. Innov. Manag. Technol., vol. 1, no. 5, pp. 511-515, 2010. 